\title{
Estimation of Total Factor Productivity Growth of Oilseed Crops in Rajasthan, India
}

\author{
Devendra Kumar Verma*, Hari Singh and Girdhari Lal Meena
}

Department of Agricultural Economics and Management, Rajasthan College of Agriculture, MPUAT, Udaipur, Rajasthan, India

*Corresponding author: devendraecon2407@gmail.com (ORCID ID: 0000-0001-9834-997X)

Received: $11-06-2021$

Revised: 26-08-2021

Accepted: 16-09-2021

\begin{abstract}
Productivity growth in agriculture is of paramount importance as higher yields are associated with declining rural poverty, suggesting that impact of growth in agricultural production on poverty remains high (Himanshu et al. 2010). The oilseed crops play an important role in agricultural development of India, sharing 14 per cent of the country's gross cropped area and accounting for about 3 per cent of the gross domestic product and nearly 6 per cent of the value of all agricultural products (ICAR-IIOR, 2015). Present study was aimed to Total Factor Productivity (TFP) growth in three oilseed crops in the state of Rajasthan during the period 2000-01 to 2015-16. In the present study, the Tornqvist Theil Index used to compute the total input index, total output index and total factor productivity index (TFPI). The Tornqvist Index is particular for the homogenous translog production function that can carry a second order approximation to an subjective twice differentiable standardized production function. The results of this study have indicated low TFP in rapeseed \& mustard4 (1.14 per cent per annum) despite a 66.38 per cent share in the total oilseed output of the state. The annual compound growth rate of TFP of soybean decreased at the rate of 0.067 per cent per annum (Negative growth). Whereas, the compound growth rate of TFP of annual green soybean crop increased at the 2.71 per cent per annum (high growth) while its TFP to output growth was about 73.26 per cent. The real cost of production of rapeseed \& mustard and soybean increased by 0.77 and 2.98 per cent per annum, respectively while $0.02 \%$ decreased in sesamum crop.

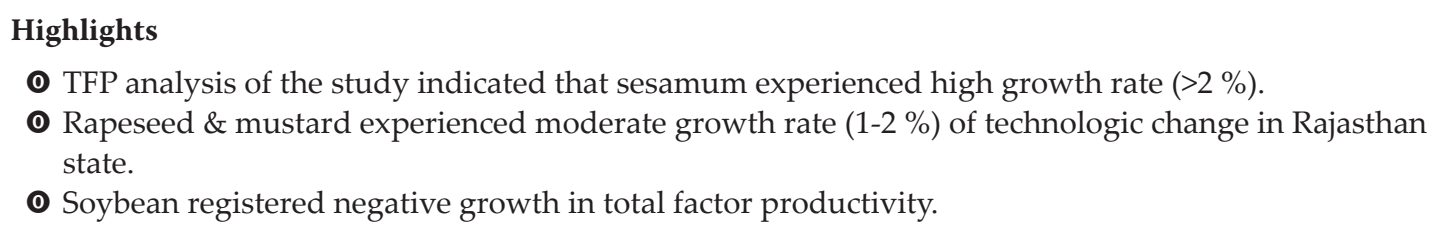

Keywords: Growth, TFP, Productivity and Production

Agriculture sector in India contributes as the most strategic component in the country's economy. Agricultural research plays an essential role in improving production of crops and livestock as the agricultural research system has expanded research productivity and research resource allocation, which are the issues of prime concern Pandya (Saikia, 2014).

Farming in India is characterized by wide differences in output and productivity growth performance amongst states and regions. For a rapid and progressive agricultural growth to meet demand of food and other raw materials, it is imperative to increase productivity growth at a sustainable rate as the scope of increasing net cultivated area is meagre. Improvement in productive efficiency of factors in agriculture is a major concern in this regard, which is also an important source of growth. Productivity, as a source of growth has been a significant premise of analytical investigation in economics all along,

How to cite this article: Verma, D.K., Singh, H. and Meena, G.L. (2021). Estimation of Total Factor Productivity Growth of Oilseed Crops in Rajasthan, India. Economic Affairs, 66(3): 527-533.

Source of Support: None; Conflict of Interest: None (c) $\oplus$ 
however it gained an empirical momentum in the recent years only and has become a necessary index to growth. The term productivity in agriculture is often used with reference to efficiency in production of land, labour and capital separately or together. Improvements in productivity can lessen the overall burden on the subsistence farming community (Pandya and Shiyani, 2002).

There are the two key measures of productivity, partial factor productivity and total factor productivity. Partial factor productivity is the ratio of output to a single input. Total Factor Productivity (TFP) is an index ratio of aggregate output to aggregate input. TFP is one of the most useful to evaluate economic performance as an ex-post facto. (Niranjan, et al. 2013). TFP may also indicate technological progress realized in an economy. The source of TFP growth is not only technological progress but also progress in the quality of inputs or efficiency improvement depending on better organization or institutional restructuring. Growth rate of agricultural produces simply depict performance of agriculture but does not reveal anything about efficiency of the performance. However, factor productivity reveals efficiency with which the factors as inputs are converted into output within production processes. Therefore, accurate measurement of TFP is crucial to understanding changes in productivity growth (Das, 2015).

\section{MATERIALS AND METHODS}

The current study is based on secondary data. Analysis has been done on the growth in output, input and total factor productivity indices of the three important oilseed crops namely, rapeseed \& mustard, soybean and sesamum over the past 17 years i.e. 1999-00 to 2015-2016. The calculating of total factor productivity (TFP) and growth rates of inputs and output, the data on input, output and prices of various crops collected under the scheme of "Cost of Cultivation of Principal Crops in Rajasthan" was obtained from the Department of Agricultural Economics and Management, MPUAT Rajasthan College of Agriculture Campus, Udaipur. The data on crop inputs included human labour (man days/ ha), bullock labour (pair days/ha), machine labour (man days/ha), seed (kg/ha), manure(tonne/ha), fertilizer ( $\mathrm{kg} / \mathrm{ha})$, insecticides (₹/ha) and irrigation (₹/ha). The expenses incurred toward depreciation $(₹ /$ ha), rental value of owned land $(₹ / h a)$, rental paid for lease in land, land revenue, taxes, cesses, interest on working and fixed capital were included under the head of miscellaneous cost.

In the present study, the Tornqvist Theil index was used for computing the total output index, total input index and total factor productivity index. TFP captures the amount of increase in total output that is not accounted for by increases in total input, but that occurs due to shift in production function, which could be to improved technology, management, knowledge, infrastructure and other knowledgebased factors. Input quantity data were available for some inputs namely seed, fertilizer, manure, human labour and bullock labour. Therefore, input quantity indices were worked out directly for each it. However, for the inputs like irrigation charges, insecticides, machine labour, rental value of land and other paid out cost, data were available only in value terms. Therefore, an indirect method has been used to compare their quantity indices. First, their value indices were prepared which were than divided with respective price indices. Due to nonavailability of such regional price indices, all India price indices for pesticides, pump driven irrigation and all commodities have been used under the assumption that the price of proxy inputs represents the price of these inputs and relative price structure remaining the same (Kumar and Parminder, 2012). These indices were calculated as follows:

\section{Total Output Index (TOI)}

Total output indices were constructed using the Tornqvist Theil index approach as follows (Olayiwola, et al. 2015):

$$
: \frac{T O I_{t}}{T O I_{t-1}} \equiv \pi_{j}\left(\frac{Q_{j t}}{Q_{j t-1}}\right)^{\left(R_{j t}+R_{j t-1}\right)^{1 / 2}}
$$

$T O I_{t}=$ Total output index in $t^{\text {th }}$ year.

$\mathrm{TOI}_{t-1}=$ Total output index in $(\mathrm{t}-1) t^{\text {th }}$ year.

$Q_{j t}=$ Output of $j^{\text {th }}$ crop in $t^{\text {th }}$ year.

$Q_{j t-1}=$ Output of $j^{\text {th }}$ crop in (t-1) $t^{\text {th }}$ year.

$R_{j t}=$ Output share of $j^{\text {th }}$ crop in total revenue in $t^{\text {th }}$ year. 
$R_{i t-1}=$ Output share of $j^{\text {th }}$ crop in total revenue in $(\mathrm{t}-1) t^{\text {th }}$ year

\section{$R_{j t}$ was calculated follows:}

$$
\begin{aligned}
& R_{j t}=\frac{\text { Value of } \mathrm{j}^{\text {th }} \text { crop output in } \mathrm{t}^{\text {th }} \text { year }}{\text { Aggregate crop output value in } \mathrm{t}^{\text {th }} \text { year }} \\
& R_{j t} \equiv Q_{j t} \times P_{j t} / \sum_{j=1}^{n} Q_{j t} \times P_{j t}
\end{aligned}
$$

Where,

$Q_{j t}=$ output of $j^{\text {th }}$ crop in $t^{\text {th }}$ year

$P_{j t}=$ Post/farm harvest price of $j^{\text {th }}$ crop in $t^{\text {th }}$ year.

Thus, total output indices for individual crops were worked out taking 1999-2000 as the base period and was multiplied to arrive TOI for crop sector. The output index includes the main product as well as by products.

\section{Total Input Index (TII)}

Total input indices were constructed using the Tornqvist Theil index approach as follows:

$$
\frac{T I I_{t}}{T I I_{t-1}} \equiv \pi_{j}\left(\frac{X_{i t}}{X_{i t-1}}\right)^{\left(S_{t}+S_{t-1}\right)^{1 / 2}}
$$

Where,

$\mathrm{TII}_{t}=$ Total input index in $t^{\text {th }}$ year.

$T I I_{t-1}=$ Total input index in ( $\left.t-1\right) t^{\text {th }}$ year.

$X_{i t}=$ Quantity of $i^{\text {th }}$ input used in $j^{\text {th }}$ crop in $t^{\text {th }}$ year.

$X_{i t-1}=$ Quantity of $i^{\text {th }}$ input used in $j^{\text {th }}$ crop in $(\mathrm{t}-1)$ $t^{\text {th }}$ year.

$S_{I t}=$ Share of input ' $i$ ' in total input cost in $t^{\text {th }}$ year.

$S_{I t-1}=$ Share of input ' $i$ ' in total input cost in (t-1) $t^{\text {th }}$ year.

Thus, input indices for individual inputs were prepared taking 1999- 2000 as the base year and was multiplied to arrive at the total input index of individual crops. The input indices for individual crops were then multiplied to get the total input index of crop sector (Rao, 2005).

\section{Total Factor Productivity Index (TFPI)}

Total factor productivity indices were computed as the ratio of total output index (TOI) to total input index (TII).

$$
\text { TFPI }_{t}=\left(T O I / \text { TII }_{t}\right) \times 100
$$

\section{RESULTS AND DISCUSSION}

Rajasthan economic performance especially after 1991 reform created good potential for export and could contribute to foreign exchange earning agricultural commodities. In order to identify farmers' specific strategy for development, it is essential to view the pattern of growth of output and input of important crops in Rajasthan. To examine the total factor productivity of crop sector in Rajasthan, 3 important oilseed crops were included in the present study.

\section{Growth in Input, Output and TFP Index of Rapeseed \& Mustard}

India is a major producer of rapeseed \& mustard and oilseeds in general. Rapeseed \& Mustard has high commercial value, and it is the principal oilseed grown in India. Mustard accounts for nearly one third of the oil produced in India, making it the country's key edible oilseed crop. Rajasthan is the largest producing state, followed by Uttar Pradesh, Haryana, Madhya Pradesh and Gujarat.

The results presented in Table 1 and Fig. 1 indicated that, the annual compound growth rate of total output, total input and TFP increased by $1.72,0.57$ and 1.14 per cent per year, respectively throughout the study period in Rajasthan state. The output index of rapeseed \& mustard fluctuated from 85.82 per cent in 2000-01 to 134.60 per cent in 2013-14. Input index varied from 91.55 per cent in 2005-06 to 127.82 per cent in the year 2015-16. It implies that input index and output index fluctuated in different years. Output indices were more than 100 for 14 years It reveals that most of the years of the study period, the output prices of rapeseed \& mustard increased.

The real cost of production and share of TFP in output growth of crops presented in Table 1. The contribution of TFP to output growth was about 66.38 per cent in during the study period. It reveals that Rajasthan state had shown average performance of TFP growth in rapeseed \& mustard crop. The technology including agronomical practices, plant protection measures and mechanization had helped to sustain TFP growth. The growth of real cost of production increased by 0.77 per cent per annum 
during the study period. The above result reflected that there was rapidly increase in the prices of inputs including labour charges.

Table 1: Growth in Input, Output and TFP Index of Rapeseed \& Mustard in Rajasthan during the Period 2000-01 to 2015-16

\begin{tabular}{|c|c|c|c|}
\hline Year & $\begin{array}{l}\text { Output } \\
\text { Index }\end{array}$ & $\begin{array}{l}\text { Input } \\
\text { Index }\end{array}$ & $\begin{array}{l}\text { TFP } \\
\text { Index }\end{array}$ \\
\hline 1999-00 & 100.00 & 100.00 & 100.00 \\
\hline 2000-01 & 85.82 & 110.98 & 77.32 \\
\hline 2001-02 & 106.66 & 104.02 & 102.53 \\
\hline 2002-03 & 112.77 & 122.83 & 91.80 \\
\hline 2003-04 & 128.88 & 112.40 & 114.66 \\
\hline 2004-05 & 94.95 & 91.60 & 103.65 \\
\hline 2005-06 & 101.18 & 91.55 & 110.51 \\
\hline $2006-07$ & 101.49 & 94.90 & 106.94 \\
\hline 2007-08 & 120.16 & 101.41 & 118.48 \\
\hline 2008-09 & 119.44 & 108.49 & 110.09 \\
\hline $2009-10$ & 101.03 & 113.13 & 89.30 \\
\hline 2010-11 & 116.25 & 92.89 & 125.14 \\
\hline 2011-12 & 129.06 & 104.55 & 123.44 \\
\hline $2012-13$ & 129.84 & 116.22 & 111.71 \\
\hline 2013-14 & 134.60 & 111.50 & 120.71 \\
\hline 2014-15 & 130.88 & 109.59 & 119.42 \\
\hline $2015-16$ & 115.14 & 127.82 & 90.07 \\
\hline CGR (\%) & 1.72 & 0.57 & 1.14 \\
\hline Real cost of production (\%) & & 0.77 & \\
\hline $\begin{array}{l}\text { Share of TFP in Output } \\
\text { growth }(\%)\end{array}$ & & 66.38 & \\
\hline
\end{tabular}

Rajasthan state had shown average performance of TFP growth in rapeseed \& mustard. The achievement of moderate growth of TFP $(>1 \%)$ for rapeseed \& mustard in Rajasthan was credited to the release of high yielding varieties viz., Pusa jai kisan (Bio 902) in 1994, Laxmi (R.H. 8812) in 1997, Vasundhara (R.H. 9304) in 2003, Pusa vijay in 2008 and Pusa mustard 30 in 2013 by the agricultural universities in Rajasthan state, which remarkably increased the productivity of rapeseed \& mustard in Rajasthan.
These finding were also in consonance with studies done by (Chand et al. 2011) in rapeseed \& mustard crop.

\section{Growth in Input, Output and TFP Index of Soybean in Rajasthan during the Period 2000- 01 to $2015-16$}

Table 2 and Fig. 2 are presented the total output, total input and total factor productivity (TFP) index of soybean during the period 2000-01 to 2015-16 in Rajasthan. The output index of soybean fluctuated from 97.54 per cent in 2004-05 to 170.69 per cent in 2003-04. Input index varied from 97.92 per cent in 2005-06 to 149.32 per cent in the year 2007-08. Total input index was more than 100 per cent in all the years except in the year 2000-01 and 200506. It implies that the input prices continuously increased during the study period, which need an urgent attention of the policy makers. The annual compound growth rates of total output index and total input index increased at the rate of 0.88 per cent per year and 1.58 per cent, respectively and the growth rate of TFP was negative about -0.67 per cent per annum. The annual compound growth rate of total input index increased more rapidly than total output index during the study period. It was found that the input prices of soybean increased higher as compared to output prices. Results so obtained were in close conformity with the finding of (Chandel, 2007) in Madhya Pradesh in soybean crop.

The soybean production in the state is heading towards unsustainability, which needs to evolve resistance to water stagnation varieties. Total factor productivity index in the state showed negative growth rate due to relatively high growth of input use compared to that of output index. It calls for better resource management strategy in the state.

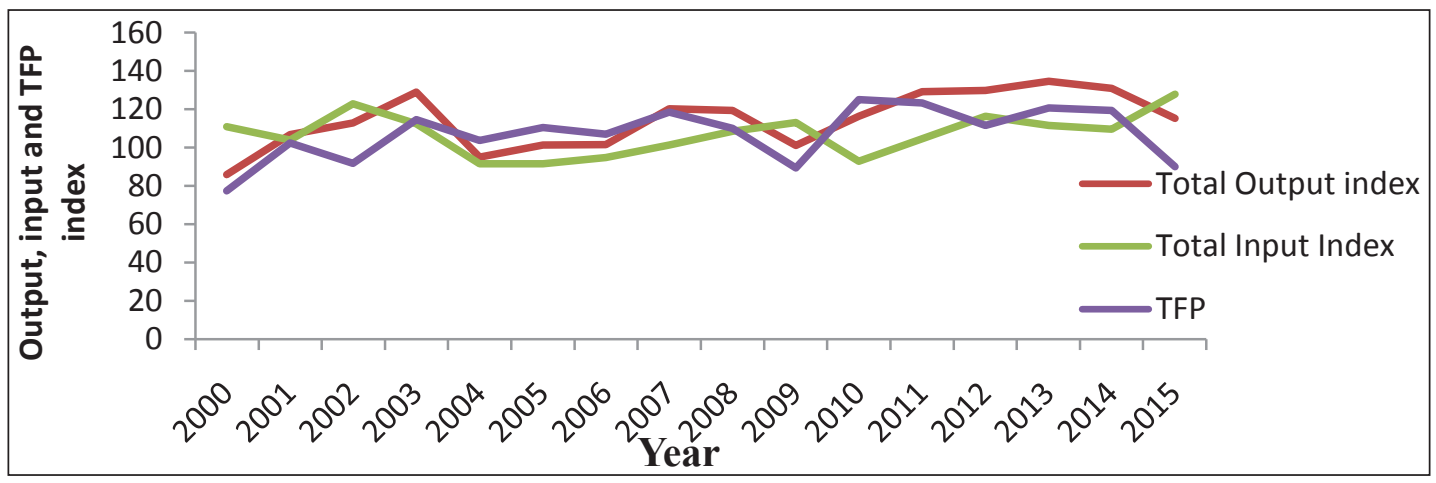

Fig. 1: Output, Input and TFP Index of Rapeseed \& Mustard in Rajasthan State for the Year 2000-01 to 2015-16 


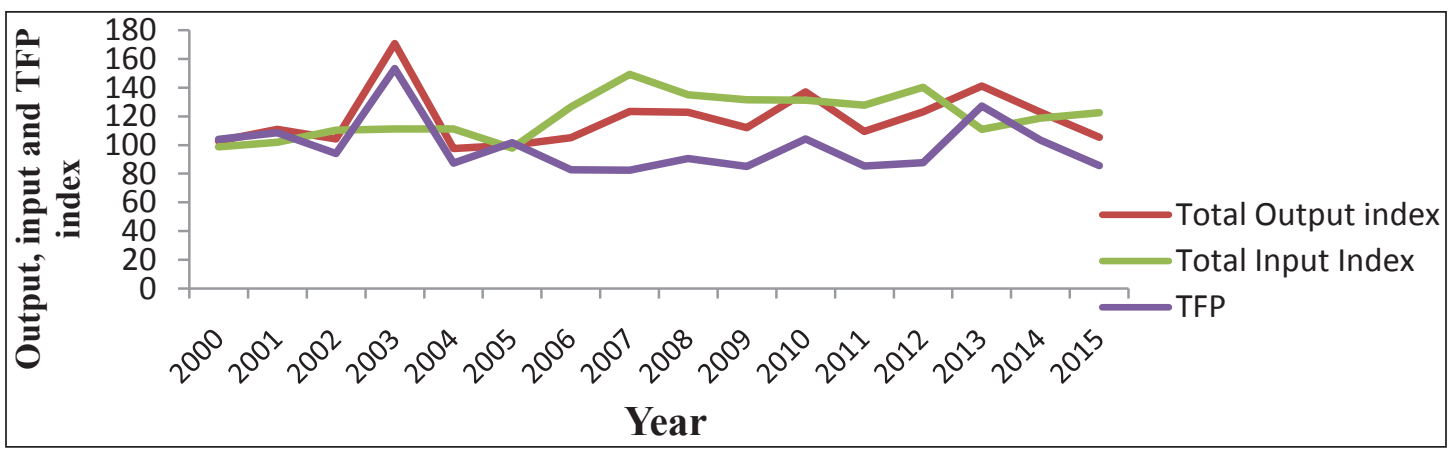

Fig. 2: Output, Input and TFP Index of Soybean in Rajasthan State for the Year 2000-01 to 2015-16

All the efforts in the state in the future have to be concentrated on accelerating the pace of total factor productivity growth.

The real cost of soybean production had increased by 2.98 per cent per annum in the state (Table 2 ). It implying the high increased the prices of inputs including labour charges but undoubtedly, research and extension efforts should be on priority to enhance productivity in soybean production.

Table 2: Growth in Input, Output and TFP index of Soybean in Rajasthan during the period 2000-01 to 2015-16

\begin{tabular}{llll}
\hline Year & $\begin{array}{l}\text { Output } \\
\text { Index }\end{array}$ & $\begin{array}{l}\text { Input } \\
\text { Index }\end{array}$ & $\begin{array}{l}\text { TFP } \\
\text { Index }\end{array}$ \\
\hline $1999-00$ & 100.00 & 100.00 & 100.00 \\
$2000-01$ & 102.72 & 98.82 & 103.94 \\
$2001-02$ & 111.01 & 102.06 & 108.76 \\
$2002-03$ & 104.13 & 110.45 & 94.27 \\
$2003-04$ & 170.69 & 111.36 & 153.29 \\
$2004-05$ & 97.54 & 111.35 & 87.59 \\
$2005-06$ & 99.76 & 97.92 & 101.87 \\
$2006-07$ & 105.18 & 126.77 & 82.96 \\
$2007-08$ & 123.40 & 149.32 & 82.64 \\
$2008-09$ & 122.66 & 135.16 & 90.75 \\
$2009-10$ & 112.06 & 131.50 & 85.21 \\
$2010-11$ & 137.03 & 131.40 & 104.28 \\
$2011-12$ & 109.51 & 127.96 & 85.58 \\
$2012-13$ & 123.21 & 140.32 & 87.80 \\
$2013-14$ & 141.14 & 111.06 & 127.08 \\
$2014-15$ & 122.85 & 118.73 & 103.47 \\
$2015-16$ & 105.30 & 122.69 & 85.82 \\
\hline CGR (\%) & 0.88 & 1.56 & -0.67 \\
\hline Real cost & & & \\
\hline
\end{tabular}

Real cost of production

2.98

(\%)

Share of TFP in Output

growth $(\%)$

\section{Growth in Input, Output and TFP Index of Sesamum in Rajasthan during the Period 2000- 01 to 2015-16}

Sesame, commonly known as ' $T i l$ ', is an ancient oil yielding crop and popularly known as "Queen of oilseeds". It is cultivated in India for its oil and is also used as a flavouring agent. India is the largest exporter of sesame in the world having annual export of 4 lakh tonnes which is almost 45 per cent of the total production. As the production in India is sufficient to satisfy the domestic consumption demand, around 45 per cent of the total production is exported to different countries. In India, Rajasthan is the highest producer of sesamum, followed by West Bengal and Gujarat (India AgriStat, 2019).

The results presented in Table 3 and Fig. 3 showed the total output, total input and TFP index of sesamum crop in Rajasthan. It revealed that the total output index fluctuated from 98.88 per cent in $2009-10$ to 247.51 per cent in 2010-11, while the input index ranged from 78.94 per cent in 2002-03 to 134.09 in 2014-15. The TFP index was more than 100 per cent in all years. It was concluded that there was efficient use of inputs and technology in sesamum crop production during the study period. The annual compound growth rate of output index, input index and TFP index were 3.70 per cent per year, 0.96 per cent per year and 2.71 per cent per year, respectively throughout the study period. The high positive TFP growth was because of technological and an infrastructural breakthrough in sesamum production system. It was realized that an appropriate policy environment, organization, institutional and favourable weather conditions were preconditions for a steady TFP growth in seasmum crop. Similar finding were also reported by (Chand et al. 2011) in rapeseed \& mustard in Gujarat state. 


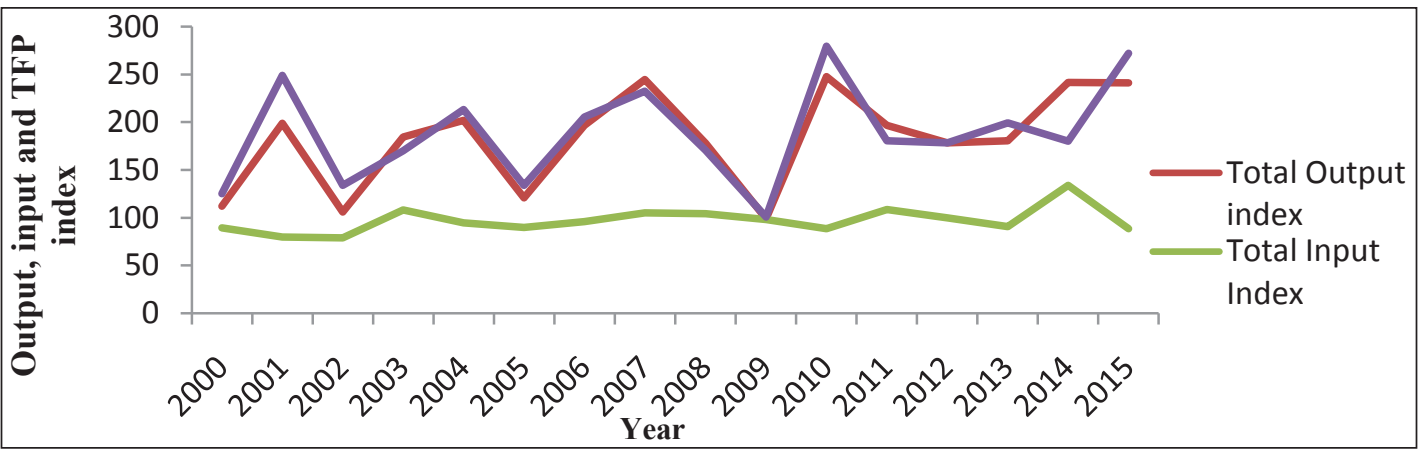

Fig. 3: Output, Input and TFP Index of Sesamum in Rajasthan State for the Year 2000-01 to 2015-16

Rajasthan state had shown an outstanding performance of TFP growth in sesamum, though the state frequently constrained by short of irrigation water in the poor monsoon. The achievement of high growth of TFP ( $>2 \%)$ for sesamum in Rajasthan state was due to the release of varieties viz., RT 125 in 1995, RT 127 in 2001, RT 346 in 2009 and RT 351 in 2011 by the different agricultural university of Rajasthan state, which remarkably increased the productivity of sesamum crop. It had also helped to reduce the real cost of production by -0.02 per cent per annum (Table 3), although the input prices including labour charges increased remarkably during the study period.

Table 3: Growth in Input, Output and TFP index of Sesamum in Rajasthan during the Period 2000-01 to 2015-16

\begin{tabular}{llll}
\hline Year & $\begin{array}{l}\text { Output } \\
\text { Index }\end{array}$ & $\begin{array}{l}\text { Input } \\
\text { Index }\end{array}$ & $\begin{array}{l}\text { TFP } \\
\text { Index }\end{array}$ \\
\hline $1999-00$ & 100.00 & 100.00 & 100.00 \\
$2000-01$ & 111.80 & 89.34 & 125.13 \\
$2001-02$ & 198.70 & 79.76 & 249.12 \\
$2002-03$ & 105.81 & 78.94 & 134.03 \\
$2003-04$ & 184.45 & 108.37 & 170.20 \\
$2004-05$ & 201.78 & 94.56 & 213.38 \\
$2005-06$ & 120.69 & 90.07 & 133.99 \\
$2006-07$ & 196.56 & 95.80 & 205.17 \\
$2007-08$ & 244.48 & 105.20 & 232.39 \\
$2008-09$ & 177.75 & 104.15 & 170.66 \\
$2009-10$ & 98.88 & 98.22 & 100.67 \\
$2010-11$ & 247.51 & 88.55 & 279.51 \\
$2011-12$ & 196.56 & 108.92 & 180.46 \\
$2012-13$ & 178.36 & 100.09 & 178.19 \\
$2013-14$ & 180.52 & 90.64 & 199.16 \\
$2014-15$ & 241.60 & 134.09 & 180.17 \\
2015-16 & 241.11 & 88.67 & 271.91 \\
\hline CGR (\%) & 3.70 & $\mathbf{3} 96$ & $\mathbf{2 . 7 1}$ \\
\hline Real cost of production (\%) & \multicolumn{3}{c}{$\mathbf{- 0 . 0 2}$} \\
\hline Share of TFP in Output & & \\
growth (\%) & & \\
\hline
\end{tabular}

The decline in the real cost of production was due to technological changes and input subsidies. The contribution of TFP to output growth was high about 73.26 per cent (Table 3) for sesamum in Rajasthan state. It reveals that Rajasthan state had shown good performance of TFP growth in sesamum crop. The technology including agronomical practices, plant protection measures and mechanization had helped to sustain TFP growth.

\section{CONCLUSION}

The annual compound growth rate of total output, total input use and TFP of rapeseed \& mustard were $1.72,0.57$, and 1.14 per cent per annum, respectively. Soybean registered negative TFP growth $(-0.67$ per cent per annum) with positive growth in total output ( 0.88 per cent per annum) and also in total input use (1.56 per cent per annum). sesamum recorded positive growth in total output, total input and TFP index were 3.70, 0.96, and 2.71 per cent per annum, respectively. To address the issue of technological progress and crop sustainability in Rajasthan, the selected crops were classified into five groups according to the magnitude of growth in TFP, as under, as given by (Chand, et al. 2011).

\begin{tabular}{ll}
\hline Negative growth & TFP growth less than zero \\
Stagnant growth & TFP growth positive but less than $0.5 \%$ \\
Low growth & TFP growth of 0.5 to $1 \%$ \\
Moderate growth & TFP growth of $>1-2 \%$ \\
High growth & TFP growth of more than $2 \%$ \\
\hline
\end{tabular}

\section{REFERENCES}

Chand, R. et al. 2011. Total Factor Productivity and Returns to Public Investment on Agricultural Research in India. Agric. Econ. Res. Rev., 25: 181-194

Chandel, B.S. 2007. How sustainable is the total factor productivity of oilseeds in India. Ind. J. Agric. Econ., 62(2): 244- 258. 
Das, V.K. 2015. Total Factor Productivity Growth of Jowar and Bajra in India. Agricul. Econ. Res. Rev., 18: 293-300.

Himanshu, L. et al. 2010. Non-farm Diversification and Rural Poverty Decline: A Perspective from Indian Sample Survey and Village Study Data. Working Paper 44. Asia Research Centre, London School of Econ Political Science, London, UK.

ICAR-IIOR, 2015. Vision 2050. ICAR-Indian Institute of Oilseeds Research, Hyderabad.

Kumar, S. and Parminder, S. 2012. Determinants of total factor productivity growth for major agricultural crops in Punjab. Ind. J. Econ. Dev., 8(2): 49-62.

Niranjan, H.K. et al. 2017. Total Factor Productivity Growth of Wheat in Madhya Pradesh. Bulletin of Env., Pharmacology and Life Sc., 6:50-54

Olayiwola, O. O. et al. 2015. Total factor productivity of major crops in central India. Int. J. Novel Res. in Civil Structural and Earth Sc., 2: 1-6.
Pandya, M.N. and Shiyani, R.L. 2002. Analysis of Total Factor Productivity Growth in Foodgrain Crops of Gujarat. Artha Vijanan, 44: 367-374.

Rao, N.C. 2005. Total Factor Productivity in Andhra Pradesh Agriculture. Econ. Res. Rev., 18: 1-19.

Saikia, D. 2014. Total factor productivity in agriculture: a review of measurement issues in the Indian context. Romanian. J. Regional Sc., 8(2): 144-152.

Suresh, A. and Reddy, A.A. 2016. Total Factor Productivity of Major Pulse Crops in India. Agricul Econ. Res. Rev., 29: 87-98.

https://www.indiastatagri.com/ 